\title{
AKTIVITAS ANTIOKSIDAN EKSTRAK METANOL DAUN KELENGKENG (Euphoria longan (L) Steud.) DENGAN METODE PENANGKAPAN RADIKAL 2,2'-DIFENIL-1-PIKRILHIDRAZIL
}

\section{ANTIOXIDANT ACTIVITY OF METHANOLIC EXTRACT OF LONGAN (Euphoria longan (L) Steud.) LEAVES USING 2,2'DIPHENYL-1-PICRYLHYDRAZYL RADICAL SCAVENGING METHOD}

\author{
Nina Salamah, Erlinda Widyasari \\ Fakultas Farmasi Universitas Ahmad Dahlan \\ Jl. Prof. Dr. Soepomo, Janturan, Yogyakarta Telp. (0274) 379418 \\ Email: ninasalamah1996@gmail.com
}

\begin{abstract}
ABSTRAK
Penyakit degeneratif disebabkan karena antioksidan yang ada di dalam tubuh tidak mampu menetralisir peningkatan konsentrasi radikal bebas, sehingga perlu adanya antioksidan dari luar untuk menghancurkan radikal bebas yang dapat menyebabkan kerusakan sel. Tujuan penelitian ini adalah untuk mengetahui aktivitas antioksidan ekstrak metanol daun kelengkeng dibandingkan dengan kuersetin. Pengujian aktivitas antioksidan ekstrak daun kelengkeng menggunakan metode penangkapan radikal 2,2'-difenil-1-pikrilhidrazil (DPPH) dan kuersetin sebagai pembanding. Data diolah menggunakan persamaan regresi linier untuk memperoleh nilai $\mathrm{ES}_{50}$ (konsentrasi yang efektif untuk menangkap radikal bebas DPPH sebanyak $50 \%$ ). Hasil penelitian menunjukkan bahwa dengan meningkatnya konsentrasi ekstrak metanol, dan pembanding kuersetin maka semakin besar pula persen penangkapan radikal bebas DPPH. Dari hasil perhitungan potensi antioksidan diperoleh nilai $\mathrm{ES}_{50}$ ekstrak metanol dan kuersetin masing-masing sebesar 40,32 dan 2,48 $\mu \mathrm{g} / \mathrm{ml}$.
\end{abstract}

Kata kunci: daun kelengkeng, Euphoria longan (L) Steud., antioksidan, DPPH, 1,1-diphenyl-2picrylhydrazyl

\begin{abstract}
The degenerative diseases is caused by endogenous antioxidant cannot neutraliced from increased concentration of free radicals, therefore it is necessary to consume antioxidant from the outside ofbody for neutralizing and destroying free radicals. The aim of this research is to evaluate the antioxidant activity of methanolic extract of longan leaves. The experiment of antioxidant activity from extract longan leaves uses the scavenging assay using 2,2'-diphenyl-1-pycrylhydrazyl (DPPH) method and quersetin as positive control. The analytical result is processed using linear regression methode in order to get $\mathrm{ES}_{50}$ value. The results of research showed that theincreasing concentration of methanolic extract, and quercetin causes the higher percentage of DPPH radical scavenging. The $\mathrm{ES}_{50}$ values of methanolic extract and quercetin obtained are $40.32 \mu \mathrm{g} / \mathrm{ml}$ and $2.48 \mu \mathrm{g} / \mathrm{ml}$ respectively.
\end{abstract}

Keywords: longan leaves, Euphoria longan (L) Steud., antioxidant, DPPH, 1,1-diphenyl-2picrylhydrazyl. 


\section{PENDAHULUAN}

Radikal bebas merupakan salah satu faktor penyebab kanker dan penyebab penyakit degeneratif lain. Penyakit kanker dan penyakit degeneratif lainnya dapat diredam apabila tubuh memiliki penangkapan radikal bebas (Hernani dan Rahardjo, 2005). Peranan antioksidan sangat penting dalam menetralkan dan menghancurkan radikal bebas yang dapat menyebabkan kerusakan sel dan juga merusak biomolekul, seperti DNA, protein, dan lipoprotein di dalam tubuh yang akhirnya dapat memicu terjadinya penyakit degeneratif, seperti kanker, jantung, artritis, katarak, diabetes dan hati (Silalahi, 2002). Radikal bebas terdiri dari Reactive Oxigen Species (ROS), Radical Nitrogen Species (RNS), dan radikal lainnya. ROS atau radikal oksigen seperti $\mathrm{O}_{2} \bullet-, \mathrm{OH} \bullet$, ROO, $\mathrm{H}_{2} \mathrm{O}_{2}$, dan ${ }^{1} \mathrm{O} 2$. RNS mencakup $\mathrm{NO} \cdot$, - $\mathrm{OONO}$, dan $-\mathrm{OONO}_{2}$. Ada juga radikal lain misalnya radikal thiil (RS•) (Punchard, 1996). Untuk menghindari hal tersebut, dibutuhkan antioksidan tambahan dari luar atau antioksidan eksogen. Radikal bebas dapat ditangkap menggunakan penangkapan radikal bebas 2,2'-difenil-1-pikrilhidrazil (DPPH). Antioksidan sebagai donor proton terhadap radikal bebas DPPH sehingga DPPH akan tereduksi menjadi stabil, dan warnanya berubah dari warna ungu menjadi warna kuning yang dapat diukur persen penangkapan radikal bebasnya pada panjang gelombang $517 \mathrm{~nm}$ (Prakash, 2001).

Metode yang digunakan untuk pengujian antioksidan adalah metode penangkapan radikal DPPH. Metode ini memiliki aktivitas penangkap radikal bebas yang tinggi dalam pelarut organik, seperti metanol atau etanol pada suhu kamar. Parameter yang digunakan untuk pengukuran aktivitas antioksidan daun kelengkeng yaitu persen penangkapan radikal dan $\mathrm{ES}_{50}$ yang diukur menggunakan spektofotometri visibel. $\mathrm{ES}_{50}$ merupakan bilangan yang menunjukkan konsentrasi efektif yang mampu menghambat aktivitas suatu antioksidan sebesar 50\% (Suryanto dkk., 2003 dan Molyneux 2004). Antioksidan berdasarkan sumber perolehannya ada 2 macam, yaitu antioksidan alami dan antioksidan buatan (sintetik). Antioksidan sintetik telah sepenuhnya diuji reaksi toksisitasnya, tapi beberapa menjadi toksik setelah penggunaan dalam waktu lama, dan data toksikologi menentukan beberapa peringatan dalam penggunaannya. Antioksidan alami ditemukan pada sebagian besar tanaman, mikroorganisme, jamur dan jaringan binatang. Sebagian besar antioksidan alami adalah komponen fenolik dan kelompok fenolik yang paling penting dari antioksidan alami adalah flavonoid dan asam fenol (Dalimartha dan Soedibyo, 1999).

Mekanisme kuersetin sebagai antioksidan sekunder adalah dengan cara memotong reaksi oksidasi berantai radikal bebas atau dengan cara menangkapnya (Winarsi, 2007). Ekstraksi kuersetin dilarutkan dalam pelarut metanol. Pelarut yang digunakan adalah pelarut yang dapat menyari sebagian besar metabolit sekunder yang diinginkan dalam simplisia (Anonim, 2008). Metanol merupakan pelarut yang bersifat universal sehingga dapat melarutkan analit yang bersifat polar dan nonpolar. Metanol dapat menarik alkaloid, steroid, saponin, dan flavonoid dari tanaman (Thompson, 1985).

Tanaman kelengkeng mempunyai senyawa bioaktif yang dapat dimanfaatkan, terutama pada bagian daunnya (Hernani dkk., 2005). Namun sampai saat ini, daun kelengkeng belum banyak dimanfaatkan oleh masyarakat dan hanya berakhir sebagai limbah. Oleh karena itu, perlu dilakukan penelitian lebih lanjut terhadap daun kelengkeng untuk membuktikan adanya aktivitas antioksidan

\section{METODE PENELITIAN}

\section{Bahan Penelitian}

Bahan yang digunakan dalam penelitian ini adalah daun kelengkeng (Euphoria longan (L) Steud.), standar kuersetin p.a (Sigma), metanol p.a (Merck), etanol absolut p.a (Merck), $\mathrm{FeCl}_{3}$ (Merck), $\mathrm{Na}_{2} \mathrm{SO}_{4}$ anhidrat (Merck), dan DPPH p.a (Sigma).

\section{Jalannya Penelitian}

\section{Determinasi tanaman}

Determinasi tanaman Euphoria longan (L) Steud. dilakukan di Laboratorium Biologi Fakultas MIPA Universitas Ahmad Dahlan, di bawah tanggung jawab kepala laboratorium. 


\section{Pengumpulan simplisia}

Daun kelengkeng diperoleh dari daerah Kampus UNY, Karangmalang, Yogyakarta pada bulan Desember tahun 2014.

3. Pembuatan serbuk dan penetapan susut pengeringan serbuk simplisia

Daun kelengkeng yang telah dikeringkan dengan oven suhu $50^{\circ} \mathrm{C}$ dibuat serbuk dan diayak dengan ayakan 40/60 mesh. Serbuk simplisia daun kelengkeng sebanyak 1 gram diletakkan di lempeng aluminium foil (khusus) kemudian dimasukkan ke dalam alat Halogen Moisture Analyzer, sehingga kadar air dari serbuk simplisia tersebut dapat diketahui.

4. Pembuatan ekstrak metanol daun

Serbuk daun kelengkeng ditimbang sebanyak 250,0 gram dan dimaserasi dengan metanol p.a hingga diperoleh ekstrak kental.

\section{Penetapan kadar air dan kadar abu ekstrak}

Ekstrak daun kelengkeng sebanyak 1 gram diletakkan dilempeng aluminium foil (khusus) kemudian dimasukkan kedalam alat Halogen Moisture Analyzer. Dikatakan memenuhi syarat apabila jumlah kadar air yang tertetapkan kurang dari 10\%. Kadar abu ditetapkan dengan metode gravimetri.

\section{Uji kualitatif kandungan ekstrak}

Uji polifenol dengan penambahan $\mathrm{FeCl}_{3}$, uji flavonoidpada kertas saring dan diuapi amoniak, Uji ada tidaknya kuersetin dengan KLT fase diam silika gel F 254 lalu di elusi dengan fase gerak toluen : etil asetat : asam formiat $(5: 4$ : 1) dan dilihat pada sinar UV $366 \mathrm{~nm}$ dan UV 254 nm (Gupta dkk., 2011).

\section{Uji penangkapan radikal DPPH kuersetin dan ekstrak uji}

Masing-masing larutan sampel dan larutan kuersetin dikocok dengan 1,0 ml larutan DPPH, campuran larutan kemudian disimpan dalam tempat gelap hingga tercapai Operating Time. Pengukuran absorbansi dibaca pada Operating Time dan panjang gelombang absorpsi maksimal yang sudah didapat.

\section{Analisis data}

Persen penangkapan radikal ekstrak metanol dihitung sesuai Persamaan 1, dengan rumus sebagai berikut:

$\%$ penangkapan radikal bebas $=\frac{S k-S s p}{s k} \times 100 \%$

Dimana, $\quad \mathrm{Sk}=$ Serapan Kontrol

Ssp = Serapan Sampel

Data-data yang diperoleh dibuat persamaan regresi linier $\mathrm{y}=\mathrm{bx}+\mathrm{a}$ berdasarkan konsentrasi dan absorbansi dari larutan standar. Dari persamaan regresi linier dihitung konsentrasi efektif penangkapan radikal $50 \%$ $\left(\mathrm{ES}_{50}\right)$ untuk masing-masing sampel.

\section{HASIL DAN PEMBAHASAN}

Simplisia yang telah mengalami proses pengeringan perlu dilakukan penetapan susut pengeringan serbuk untuk mengetahui kandungan air yang terdapat dalam serbuk simplisia yang telah dikeringkan. Kandungan air yang tinggi dalam simplisia dapat menjadi media pertumbuhan kapang dan jamur. Selain itu, kandungan air yang tinggi juga dapat terjadi reaksi enzimatik yang dapat menguraikan zat aktif pada simplisia. Standar kadar air dalam simplisia yang sudah dikeringkan yaitu kurang dari 10\% (Anonim, 2008). Penetapan susut pengeringan serbuk simplisia daun kelengkeng dilakukan dengan menggunakan alat Halogen Moisture Analyzer. Prinsip kerja dari alat Halogen Moisture Analyzer yaitu gravimetri. Rata-rata kadar air dari simplisia daun kelengkeng adalah 5,54\%. Berdasarkan kadar air yang ditetapkan dapat dikatakan simplisia yang digunakan memenuhi syarat FHI.

Metode penyarian yang digunakan dalam penelitian adalah metode maserasi. Metode maserasi merupakan ekstraksi dengan pelarut cara dingin, tidak memerlukan pemanasan yang 
dapat merusak zat aktif dalam daun kelengkeng. Proses maserasi menggunakan pelarut metanol p.a hingga ampas yang diperoleh apabila ditetesi dengan larutan $\mathrm{FeCl}_{3}$ tidak terbentuk warna hijau-biru, hitam pekat. Hal ini menunjukkan proses maserasi yang optimal, sehingga zat aktif yang terkandung di dalam daun kelengkeng tersari seluruhnya. Pada penelitian dilakukan proses remaserasi hingga 3 kali. Proses yang terjadi selama maserasi yaitu proses difusi. Proses difusi dipengaruhi oleh beberapa faktor, salah satu faktor tersebut adalah pengadukan (Khopkar, 2008). Pengadukan pada proses maserasi dilakukan dengan pengaduk elektrik yang bertujuan untuk meningkatkan kontak antar serbuk simplisia dengan pelarut sehingga zat-zat aktif dalam serbuk simplisia banyak yang tersari dalam larutan penyari. Lama pengadukan kurang lebih selama 3 jam kemudian didiamkan selama 24 jam untuk memberikan kesempatan pada zat aktif yang tersari di dalam sel untuk berdifusi keluar sel.

Penggunaan metanol sebagai pelarut diharapkan dapat melarutkan senyawa flavonoid dan fenolik. Selain itu, metanol juga bersifat universal sehingga dapat menarik sebagian besar senyawa kimia yang terkandung di dalam simplisia (polar dan non polar). Filtrat yang diperoleh dengan penyaringan menggunakan corong Buchner yang dihubungkan dengan pompa vakum. Filtrat yang diperoleh dikumpulkan kemudian diuapkan menggunakan rotary evaporator pada suhu $50^{\circ} \mathrm{C}$ sehingga terbentuk ekstrak cair. Keuntungan penggunaan rotary evaporator yaitu suhu pada proses penguapan dapat dikontrol sehingga dapat menghindari kerusakan zat aktif karena pemanasan. Selain itu, dapat meminimalisir kontak zat aktif dengan udara yang dapat menyebabkan terjadinya reaksi oksidasi. Setelah itu, ekstrak cair yang diperoleh lalu diuapkan di atas penangas air dengan suhu $50^{\circ} \mathrm{C}$. Ekstrak kental didiamkan dalam suhu kamar. Ekstrak yang diperoleh ditimbang dan dihitung rendemennya. Hasil rendemen ektrak metanol daun kelengkeng 20,07\%. Hasil pengukuran susut pengeringan ekstrak metanol daun kelengkeng adalah 6,26\%. Berdasarkan kadar air yang ditetapkan dapat dikatakan ekstrak yang digunakan memenuhi syarat. Selanjutnya, dilakukan pengukuran kadar abu total untuk mengetahui kandungan mineral suatu bahan. Kadar abu yang tinggi menunjukan semakin tinggi pula kandungan unsur mineral dalam ekstrak seperti logam. Kandungan logam yang tinggi akan menurunkan aktivitas antioksidan karena selain menangkap radikal bebas, antioksidan juga mengkhelat logam (Sibuea, 2004). Hasil percobaan menunjukan bahwa kadar abu rata-rata ekstrak metanol daun kelengkeng yaitu $0,44 \%$. Persyaratan kadar abu total yaitu $\leq$ 0,5\% (Anonim, 2008). Berdasarkan penetapan kadar abu yang ditetapkan dapat dikatakan ekstrak yang digunakan memenuhi syarat.

Senyawa flavonoid dan polifenol merupakan senyawa aktif yang terdapat dalam daun kelengkeng. Senyawa tersebut berpotensi sebagai antioksidan. Oleh karena itu, dilakukan pemeriksaan senyawa flavonoid dan polifenol terhadap ekstrak metanol daun kelengkeng. Hasil uji polifenol dapat dilihat pada Tabel I. Warna yang terbentuk pada uji polifenol merupakan hasil reaksi antara senyawa polifenol dan ferri klorida membentuk kompleks $\mathrm{Fe}^{3+}$-polifenol. Atom oksigen pada polifenol mempunyai pasangan elektron bebas yang dapat mendonorkan elektronnya pada $\mathrm{Fe}^{3+}$ yang mempunyai orbital d kosong membentuk ikatan kovalen koordinasi sehingga menjadi suatu kompleks yang berwarna hijau-biru, hitam pekat (Mustarichie dkk., 2011).

Selanjutnya, dilakukan uji flavonoid yang bertujuan untuk memastikan kandungan flavonoid dalam ekstrak daun kelengkeng. Adanya senyawa flavonoid ditandai dengan timbulnya warna kuning intensif pada kertas saring sampel yang diuapi amoniak. Warna kuning disebabkan pembentukan struktur kuinoid pada cincin $\beta$ yang mengandung ikatan rangkap terkonjugasi yang lebih panjang (Robinson, 1995). Hasil uji flavonoid dapat dilihat pada Tabel II.

Uji kandungan kuersetin menggunakan Kromatografi Lapis Tipis (KLT) dengan fase gerak toluen : etil asetat : asam formiat $(5: 4: 1)$ 
dan fase diam silika gel F 254. Setelah elusi, hasil KLT dilihat pada sinar UV $366 \mathrm{~nm}$ menghasilkan flouroresensi ungu padam dan pada sinar UV 254 nm menghasilkan warna kuning kecoklatan.

Hasil KLT menunjukan bahwa ekstrak metanol daun kelengkeng menghasilkan bercak lebih banyak dibandingkan fraksi etil asetat daun kelengkeng. Hal ini dikarenakan pelarut metanol bersifat universal. Selain melarutkan analit yang bersifat polar maupun non polar, pengotor pun juga akan ikut tersari. Pengotor ini akan menggangu proses penangkapan radikal bebas. Semakin besar nilai $\mathrm{ES}_{50}$ maka semakin kecil kemampuan senyawa untuk menangkap radikal bebas (Thompson, 1985).
Ekstrak metanol daun kelengkeng mempunyai kandungan kuersetin. Hasil ini ditunjukkan dengan munculnya bercak yang sama antara ekstrak dan fraksi dengan standar kuersetin. Data harga Rf ekstrak metanol, fraksi etil asetat, dan standar kuersetin dapat dilihat pada Tabel III, sedangkan hasil KLT pada UV $254 \mathrm{~nm}$ dan UV $366 \mathrm{~nm}$ dapat dilihat pada Gambar 1.

Harga Rf ekstrak metanol daun kelengkeng mendekati Rf standar kuersetin, sehingga dapat dikatakan bahwa ekstrak metanol daun kelengkeng mengandung kuersetin.

Tabel I. Hasil uji polifenol standar kuersetin, ekstrak metanol daun kelengkeng

\begin{tabular}{lllll}
\hline Nama Sampel & Pereaksi & Sebelum & Sesudah & Keterangan \\
\hline Standar kuersetin & $\mathrm{FeCl}_{3}$ & A & $\begin{array}{l}\text { Terjadi perubahan warna kuning } \\
\text { menjadi hijau-biru, hitam pekat }\end{array}$ \\
$\begin{array}{l}\text { Ekstrak metanol } \\
\text { daun kelengkeng }\end{array}$ & $\mathrm{FeCl}_{3}$ & $\mathbf{B}$ & $\begin{array}{l}\text { Terjadi perubahan warna kuning } \\
\text { menjadi hijau-biru, hitam pekat }\end{array}$ \\
& & & & \\
\end{tabular}

Tabel II. Hasil uji flavonoid standar kuersetin, ekstrak metanol daun kelengkeng

\begin{tabular}{|c|c|c|c|c|}
\hline Nama Sampel & Pereaksi & Sebelum & Sesudah & Keterangan \\
\hline $\begin{array}{l}\text { Standar } \\
\text { kuersetin }\end{array}$ & Uap $\mathrm{NH}_{3}$ & A & $\bar{A}$ & $\begin{array}{l}\text { Perubahan warna kuning pucat } \\
\text { menjadi kuning intensif }\end{array}$ \\
\hline $\begin{array}{l}\text { Ekstrak metanol } \\
\text { daun } \\
\text { kelengkeng }\end{array}$ & Uap $\mathrm{NH}_{3}$ & B & B & $\begin{array}{l}\text { Perubahan warna kuning pucat } \\
\text { menjadi kuning intensif }\end{array}$ \\
\hline
\end{tabular}


Tabel III. Nilai Rf ekstrak metanol dan standar kuersetin

\begin{tabular}{ll}
\hline Sampel & Nilai Rf Kuersetin \\
\hline Ekstrak Metanol & 0,43 \\
Standar Kuersetin & 0,44 \\
\hline
\end{tabular}

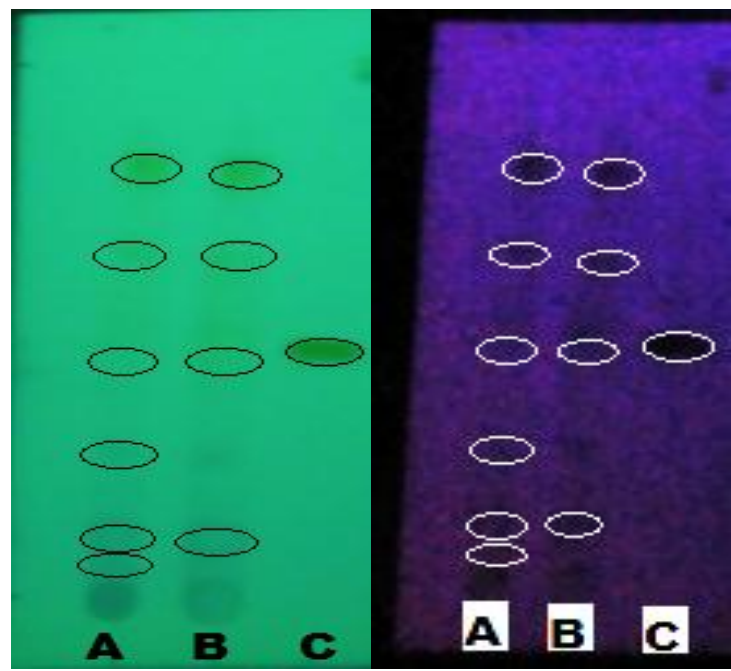

Keterangan :

A. Ekstrak uji

B. Fraksi

C. Standar kuersetin

A

B

\section{Gambar 1. Hasil KLT pada UV 254 nm (A) dan UV 366 nm (B)}

Tahap awal pengujian senyawa dengan menggunakan spektrofotometer visibel adalah menentukan waktu operasional (operating time). Waktu operasional merupakan waktu pengukuran saat larutan menyerap sinar dengan serapan yang stabil. Serapan yang stabil ini menunjukkan bahwa DPPH telah bereaksi optimal dengan senyawa uji dan standar kuersetin. Hasil penelitian, standar kuersetin menunjukan serapan yang stabil pada menit ke-25,3 sampai menit ke64,7; larutan ekstrak metanol daun kelengkeng pada menit ke-40 sampai menit ke-120.

Pengukuran absorbansi dilakukan pada panjang gelombang serapan maksimal, yaitu panjang gelombang yang mempunyai absorbansi maksimal. Pada panjang gelombang maksimal akan diperoleh absorbansi yang maksimal. Panjang gelombang serapan maksimal yang digunakan adalah panjang gelombang maksimal kontrol negatif DPPH, karena pada prinsipnya absorbansi yang diukur adalah absorbansi larutan DPPH yang tidak bereaksi dengan senyawa antioksidan. Secara teoritis, panjang gelombang maksimum untuk larutan DPPH dalam etanol adalah 515-517 nm (Suryanto dkk., 2003). Hasil penelitian menunjukan bahwa panjang gelombang maksimum untuk larutan DPPH adalah 517,2 nm dengan nilai absorbansi sebesar 0,657 untuk kuersetin, untuk panjang gelombang maksimum larutan DPPH adalah 515,8 nm dengan nilai absorbansi sebesar 0,619 untuk ekstrak metanol daun kelengkeng.

Untuk membuktikan bahwa absorbansi yang terukur adalah sisa DPPH maka dilakukan pengukuran panjang gelombang maksimum kuersetin dan larutan sampel tanpa DPPH. Hasil pengukuran kuersetin dan larutan sampel tanpa DPPH tidak memiliki puncak absorbansi pada panjang gelombang maksimum DPPH sehingga disimpulkan bahwa absorbansi yang terukur adalah sisa DPPH yang tidak ditangkap oleh senyawa uji. Hal ini diperkuat oleh Markham (1988) bahwa rentang serapan spektrum flavonol (kuersetin) mempunyai panjang gelombang 350$385 \mathrm{~nm}$ pada pita pertama dan pita kedua pada panjang gelombang 250-280 nm. Sampel yang digunakan adalah ekstrak metanol daun kelengkeng dan sebagai kontrol positif digunakan kuersetin. Kuersetin dipilih sebagai kontrol positif karena telah terbukti mempunyai antivitas penangkapan radikal bebas karena kuersetin memiliki gugus $\mathrm{OH}$ pada posisi 3', 4', 3, 5, dan 
7. Pengujian aktivitas penangkapan radikal bebas ekstrak dan fraksi daun kelengkeng dilakukan dengan menggunakan metode DPPH. Pertimbangan dari metode tersebut karena metode DPPH merupakan metode yang relatif mudah dan sederhana dalam pengerjaannya. Sebelum dilakukan pengujian aktivitas penangkapan radikal bebas DPPH pada sampel, perlu dilakukan validasi metode penelitian. Validasi metode penelitian menggunakan senyawa standar yang telah diketahui aktivitas penangkapan radikal bebas sebagai kontrol positif. Kemampuan larutan ekstrak kelengkeng dalam menangkap radikal bebas DPPH dapat dilihat dari berkurangnya intensitas warna ungu dari larutan DPPH setelah ditambahkan sampel. Pengurangan intensitas warna tersebut disebabkan oleh bereaksinya molekul radikal DPPH dengan satu atom hidrogen yang dilepaskan oleh sampel sehingga terbentuknya senyawa DPPH yang berwarna kuning stabil. Senyawa fenol yang terdapat dalam sampel kehilangan atom $\mathrm{H}$ yang akan menjadi radikal bebas baru yang stabil dan tidak reaktif karena adanya efek resonansi inti aromatik.

Pengukuran aktivitas antioksidan pada penelitian ini dilakukan secara kuantitatif dengan menggunakan metode spektrofotometri visibel. Pengukuran aktivitas antioksidan ditandai dengan adanya penurunan absorbansi larutan DPPH yang telah ditambahkan sampel. Absorbansi yang terukur adalah absorbansi sisa DPPH yang tidak ditangkap oleh senyawa flavonoid dalam sampel. Semakin kecil absorbansi larutan uji, maka aktivitas penangkapan radikal bebas semakin besar. Senyawa yang dicurigai memiliki aktivitas antioksidan pada penelitian ini adalah flavonoid. Reaksi penangkapan radikal bebas terjadi oleh flavonoid dapat dilihat pada Gambar 2. Dari data absorbansi dihitung persen penangkapan radikal bebas dan $\mathrm{ES}_{50}$. Persen penangkapan radikal bebas digunakan untuk membandingkan aktivitas penangkapan radikal bebas DPPH kuersetin dan ekstrak. Sedangkan ES $_{50}$ merupakan konsentrasi efektif senyawa uji yang menghasilkan aktivitas penangkapan radikal DPPH sebesar 50\%. Harga $\mathrm{ES}_{50}$ dapat ditentukan menggunakan persamaan garis regresi linier antara konsentrasi sebagai sumbu X dan persen penangkapan radikal bebas sebagai sumbu Y. Data penangkapan radikal bebas dan nilai $\mathrm{ES}_{50}$ pada kuersetin danekstrak metanol daun kelengkeng. dapat dilihat secara berturut-turut pada Tabel IV dan V. Tabel IV dan $\mathrm{V}$ menunjukan bahwa semakin besar konsentrasi maka semakin besar persen penangkapan radikal bebas DPPH. Hasil analisis diketahui bahwa persamaan garis regresi linier antara konsentrasi senyawa dengan persen penangkapan radikal bebas DPPH memiliki nilai besaran korelasi ( $\mathrm{r}$ hitung) yang lebih besar dari $r$ tabel (dengan probabilitas 0,95) sehingga korelasi kedua besaran tersebut adalah bermakna dan persamaan regresi linier tersebut dapat digunakan. Data persen penangkapan radikal DPPH pada berbagai konsentrasi dapat dihitung nilai $\mathrm{ES}_{50}$. Nilai $\mathrm{ES}_{50}$ rata-rata untuk kuersetin, ekstrak metanol daun kelengkeng, dan fraksi etil asetat daun kelengkeng berturut-turut yaitu $2,48 \mu \mathrm{g} / \mathrm{ml} ; 40,32$ $\mu \mathrm{g} / \mathrm{ml}$; dan $12,59 \mu \mathrm{g} / \mathrm{ml}$.

Potensi aktivitas antioksidan masingmasing sampel dapat dilihat dari nilai $\mathrm{ES}_{50}$. Nilai $\mathrm{ES}_{50}$ berbanding terbalik dengan kemampuan senyawa menangkap radikal bebas DPPH, semakin kecil $\mathrm{ES}_{50}$ maka semakin besar kemampuan senyawa untuk menangkap radikal bebas. Nilai $\mathrm{ES}_{50}$ ekstrak metanol > kuersetin berarti bahwa kemampuan aktivitas penangkapan radikal bebas yang paling besar adalah kuersetin.

Uji Kolmogorov-Smirnov diperoleh dengan nilai signifikansi 0,143 lebih besar dari 0,050 yang menunjukan bahwa data terdistribusi normal. Selanjutnya, dilakukan uji Levene untuk menentukan homogenitas data. Hasil uji Levene diperoleh nilai signifikansi 0,031 lebih kecil dari 0,050 yang menunjukan bahwa data tidak homogen. Data tidak memenuhi syarat untuk uji parametrik yaitu harus terdistribusi normal dan homogen maka dilakukan uji dengan analisis statistik non parametrik menggunakan metode Kruskal-Wallis dengan taraf kepercayaan $95 \%$. Hasil uji Kruskal-Wallis diperoleh nilai signifikansi 0,002 kurang dari 0,050 artinya bahwa terdapat perbedaan yang bermakna antara nilai $\mathrm{ES}_{50}$ kuersetin dan ekstrak metanol daun kelengkeng. 


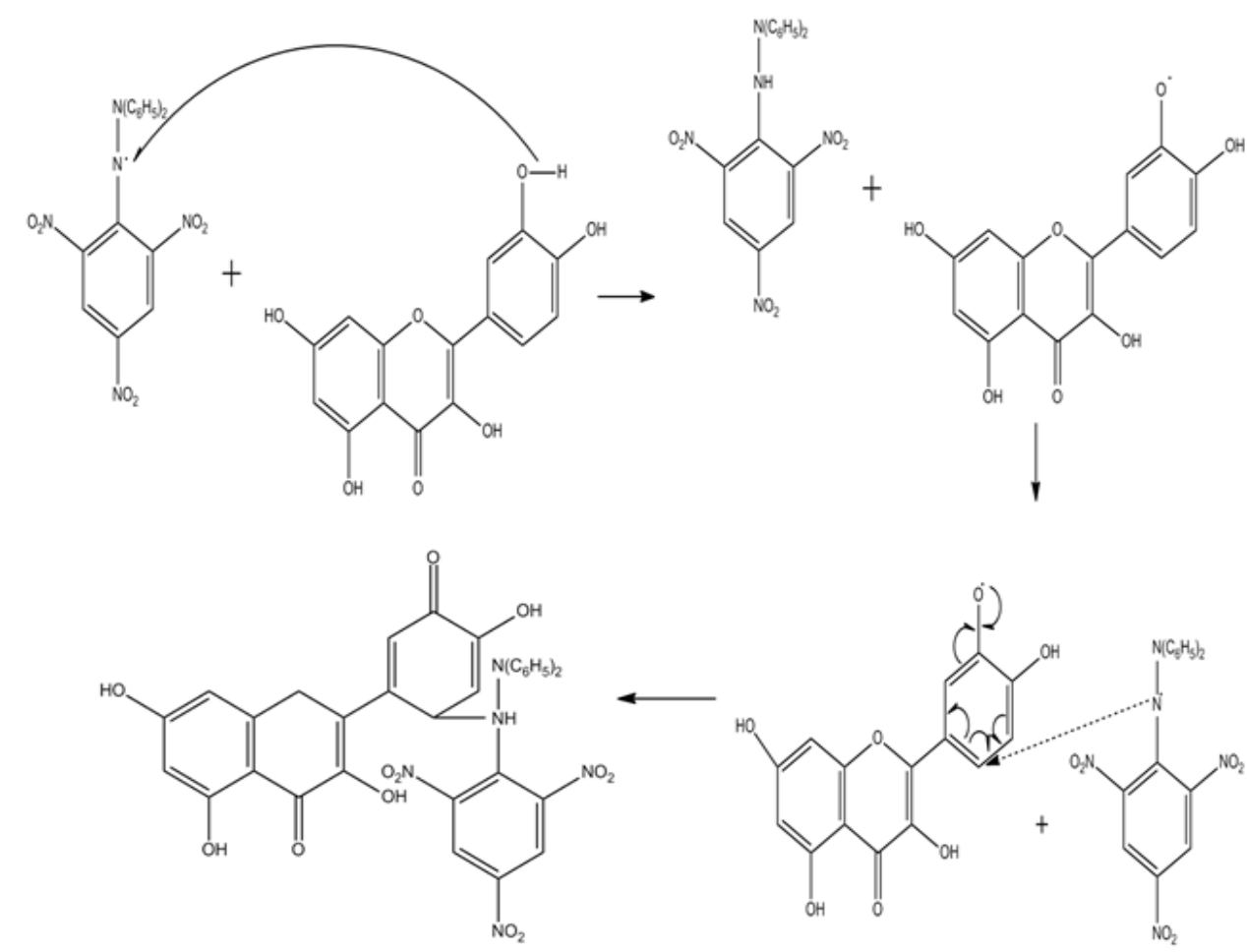

Gambar 2. Reaksi antara antioksidan (flavonoid) dengan radikal DPPH (Molyneux, 2004)

Tabel IV. Persen penangkapan radikal bebas dan nilai ES $_{50}$ kuersetin

\begin{tabular}{|c|c|c|c|c|c|c|c|c|c|}
\hline \multirow[t]{2}{*}{ No } & \multicolumn{7}{|c|}{$\begin{array}{c}\text { \% Penangkapan Radikal Bebas pada Konsentrasi } \\
\text { Kuersetin }(\mu \mathrm{g} / \mathrm{ml})\end{array}$} & \multirow{2}{*}{$\begin{array}{c}\text { Persamaan } \\
\text { Regresi Linier }\end{array}$} & \multirow[t]{2}{*}{$\mathrm{ES}_{50}(\mu \mathrm{g} / \mathrm{ml})$} \\
\hline & 2 & 1,75 & 1,5 & 1,25 & 1 & $\mathbf{0 , 7 5}$ & 0,5 & & \\
\hline 1 & 41,19 & 32,62 & 20,76 & 16,31 & 12,52 & 9,06 & 6,59 & $y=22,737 x-8,557$ & 2,57 \\
\hline 2 & 40,69 & 35,09 & 28,01 & 21,09 & 16,14 & 12,19 & 7,25 & $y=22,570 x-5,290$ & 2,45 \\
\hline 3 & 38,71 & 32,45 & 26,03 & 13,67 & 11,70 & 9,23 & 2,31 & $\mathrm{y}=24,281 \mathrm{x}-11,195$ & 2,52 \\
\hline 4 & 40,69 & 31,14 & 26,85 & 15,81 & 11,37 & 7,91 & 2,96 & $y=25,019 x-11,740$ & 2,47 \\
\hline 5 & 43,66 & 31,96 & 28,83 & 18,78 & 11,70 & 8,73 & 7,41 & $y=24,620 x-9,194$ & 2,40 \\
\hline $\begin{array}{ll}\mathrm{Re1} \\
\mathrm{CV}\end{array}$ & $\pm \mathrm{LE}$ & & & & & & & & $\begin{array}{l}2,48 \pm 0,09 \\
2,82 \%\end{array}$ \\
\hline
\end{tabular}

Keterangan $=r$ hitung $>r$ tabel

Tabel V. Persen penangkapan radikal bebas dan nilai $\mathrm{ES}_{\mathbf{5 0}}$ ekstrak metanol daun kelengkeng

\begin{tabular}{|c|c|c|c|c|c|c|c|c|c|}
\hline \multirow[t]{2}{*}{ No } & \multicolumn{7}{|c|}{$\begin{array}{l}\text { \% Penangkapan Radikal Bebas pada Konsentrasi } \\
\text { Ekstrak Metanol Daun Kelengkeng }(\mu \mathrm{g} / \mathrm{ml})\end{array}$} & \multirow{2}{*}{$\begin{array}{c}\text { Persamaan Regresi } \\
\text { Linier }\end{array}$} & \multirow[t]{2}{*}{$\mathbf{E S}_{50}(\mu \mathrm{g} / \mathrm{ml})$} \\
\hline & 40 & 35 & 30 & 25 & 20 & 15 & 10 & & \\
\hline 1 & 53,43 & 47,02 & 41,83 & 35,11 & 34,50 & 25,04 & 17,86 & $y=1,129 x+8,184$ & 37,04 \\
\hline 2 & 50,38 & 44,88 & 38,01 & 35,88 & 34,66 & 26,56 & 25,04 & $y=0,829 x$ & 41,29 \\
\hline 3 & 50,84 & 42,90 & 37,86 & 33,74 & 29,16 & 24,12 & 19,39 & $y=1,004 x+8,892$ & 40,94 \\
\hline 4 & 50,23 & 42,59 & 37,71 & 33,13 & 27,02 & 24,12 & 20,15 & $y=0,985 x+8,945$ & 41,68 \\
\hline 5 & 52,06 & 42,90 & 36,95 & 34,20 & 28,55 & 24,58 & 19,85 & $y=1,012 x+8,857$ & 40,65 \\
\hline $\begin{array}{l}\text { Rer } \\
\text { CV }\end{array}$ & $\mathrm{LE}$ & & & & & & & & $\begin{array}{l}40,32 \pm 2 \\
4,64 \%\end{array}$ \\
\hline
\end{tabular}

Keterangan $=r$ hitung $>r$ tabel 


\section{KESIMPULAN}

Ekstrak metanol daun kelengkeng memiliki aktivitas antioksidan dengan metode penangkapan radikal DPPH. Nilai $\mathrm{ES}_{50}$ rata-rata dari ekstrak metanol daun kelengkeng sebesar $40,32 \pm 2,32 \mu \mathrm{g} / \mathrm{ml}$. Hasil analisis ini menunjukkan bahwa ekstrak metanol daun kelengkeng mempunyai aktivitas antiradikal yang lebih kecil dibanding dengan kuersetin (nilai $\mathrm{ES}_{50}$ sebesar 2,48 $\pm 0,09 \mu \mathrm{g} / \mathrm{ml})$.

\section{DAFTAR PUSTAKA}

Dep Kes RI, 2008, Farmakope Indonesia edisi $I V$, Departemen Kesehatan Republik Indonesia, Jakarta, 9.

Anonim, 2008, Farmakope Herbal Indonesia, Edisi 1,Departemen Kesehatan Republik Indonesia, Jakarta.

Dalimartha, S., dan Soedibyo M., 1999, Awet Muda dengan Tumbuhan Obat dan Diet Suplemen, Trubus Agriwidya.

Gupta, Rajiv, Sakshi Sehgal, dan Shubhini A. Saraf, 2011, Quantitative Estimation of Quercetin in Mimusops elengi L. (Bakul) Leaves by HPTLC, Der Pharmacia Lettre, 3(5): 12-19.

Hernani dan Raharjo M, 2005, Tanaman Berkhasiat Antioksidan, Penebar Swadya, Jakarta.

Khopkar, S.M., 2008, Konsep Dasar Kimia Analitik, UI Press, Jakarta.

Markham, K.R., 1988, Cara Mengidentifikasi Flavonoid, diterjemahkan oleh Kosasih Padmawinata, Penerbit ITB, Bandung.

Molyneux, P., 2004, The use of the stable free radical diphenylpicrylhydrazyl (DPPH) for estimating antioxidant activity, Journal Science of Technology.
Mustarichie, R., I. Musfiroh, dan J. Levita, 2011. Metode Penelitian Tanaman Obat, Widya Padjadjaran, Bandung.

Prakash, A., 2001, Antioxidant Activity, Medallion Laboratories Analytical Progress, 19: 2.

Punchard, N. A., F.J. Kelly, 1996, Free Radical, Oxford University Press, New York, 1.

Robinson, T., 1995, Kandungan Organik Tumbuhan Tinggi, Edisi VI, diterjemahkan Padmawinata, K, Institut Teknik Bandung, Bandung, 57.

Sastrohamidjojo, H., 1991, Kromatografi, Edisi Kedua, Liberty, Yogyakarta.

Sibuea, P., 2004, Kuersetin Senjata Pemusnah Radikal Bebas, http://Kompas.com/Kompascetak/0402/1 0/humaniora/840926.htm.

Silalahi, J., 2002, Senyawa polifenol sebagai komponen aktif yang berkhasiat dalam teh. Majalah Kedokteran Indonesia., 52 (10): 361-4.

Suryanto, E., Sastroamidjojo H., Raharjo S., dan Tranggono, 2003, Antiradical of Andaliman (Zanthoxylum acanthopodium DC) Fruit Extract, Departement of Chemistry, Fac of Mathematic and Natural Science, Gadjah Mada Univercity, Yogyakarta.

Thompson, E. B, 1985, Drug Bioscreening, Graceway Publishing Company, Inc, America, 40: 118.

Usman, 2004, Sukses Membuahkan Lengkeng dalam Pot, PT Agromedia Pustaka, Jakarta.

Winarsi, H., 2007, Antioksidan Alami dan Radikal Bebas, Penerbit Kanisius, Yogyakarta. 
